\title{
Decentralisation of City Administration and Competences of Decentralised City Units
}

\section{Dejan Vučetič}

UDK

351.071.55/.6(4)

Review scientific paper / pregledni znanstveni rad

Received / primljeno: 29.6. 2015.

Accepted / prihvaćeno: 1. 4. 2016.

A balanced city system, coordination, and cooperation between city units are necessary preconditions for effective governance, as well as for avoiding internal imbalances and underdevelopment. The first part the paper focuses on the legal position of inner city units in European cities (primarily those in Central Europe), with specific reference to the effectiveness of administration and democratic processes. The second part analyses city administration and competences of city units in Serbian cities, internally divided into city municipalities. Neither Serbian local government regulations nor legal theory have sufficiently defined the legal nature and position of city municipalities. The analysis focuses on the statutes regulating the internal organisation of six cities for the purpose of examining the administrative bodies and competences of city municipalities. These statutes do not regulate all the issues necessary for the successful operation of city municipalities; moreover, some municipalities exist only in statutes and not in reality.

Keywords: decentralisation, local government, cities, city municipalities, public administration

* Dejan Vučetić, PhD, Assistant Professor, Faculty of Law, University of Niš, Serbia (docent na Pravnom fakultetu Sveučilišta u Nišu, Srbija, e-mail: dvucetic@prafak.ni.ac.rs) 


\section{Introduction}

The classic organisation of city administration dates back to the period featuring the dominance of agricultural areas over urban areas. However, in due course, administrative systems in modern states have gradually become distinguished by a high degree of urbanisation, the consequence of which is a larger and wider regional impact of cities. Large cities are increasingly assuming a leading role in the development of their states and, according to the data provided by the UN (UN, 2014: 7), this role will keep expanding in the future. Due to their social, economic, and political potential, the complexity of relations they entail, as well as the number of problems underlying their operation, the study of large cities cannot be reduced to discussing the classical problems of local self-government; on the contrary, it must be given a broader theoretical dimension, which would reflect the similar efforts of many administrative systems to respond to the changing circumstances by acknowledging the special legal status of cities. For example, the Italian Constitution recognises the special constitutional status of large cities in Article 114/1: "The Republic is composed of Municipalities, Provinces, Metropolitan Cities, Regions, and the State. Municipalities, provinces, metropolitan cities, and regions are autonomous entities having their own statutes, powers, and functions in accordance with the principles laid down in the Constitution." (Pajvančić, 2009: 6).

An ordinary city turns into a large city by transforming the quantitative characteristics of its growth into qualitative ones, and by creating a complex system which includes surrounding areas that gravitate towards it (Vujčić, 1981: 53). For the purposes of this paper, a city may be defined as a populated centre characterised by a higher level of economic, social, cultural, urban, scientific, and political growth. The distinctive legal status of cities guarantees them a higher level of independence in relation to basic local self-government units, which necessarily gives rise to a greater number of original and assigned competences and, in certain systems, a greater number of direct revenues (Dimitrijević \& Vučetić, 2011: 137). The consequence of acknowledging a special legal status of cities, which is most frequently accomplished by enacting a systemic legislative framework on local self-government, necessarily implies a precise regulation of the relationships between the city and its suburban municipalities due to their resistance to forming centralised institutional relations (Jovičić, 2006: 66). Their relationships must be based on the principles of coordination and cooperation, which are to provide for an efficient operation of 
a large city system and prevent a growing imbalance between developed and underdeveloped parts within the same urban area. It is very common practice that the relations between the city and its suburban municipalities are regulated by contract, primarily in the field of providing utility services, transportation, urban development planning, and environmental protection. However, in order to maintain a sustainable and fair balance between the city units, it is essential to reduce to some extent the independence and autonomy of city decentralisation units and concurrently reinforce the cooperation, communication, and exchange of information inside the city system (Dimitrijević \& Vučetić, 2011: 139).

The European Charter on Local Self-Government does not recognise cities as separate forms of local self-government. On the other hand, the Congress of Local and Regional Authorities of the Council of Europe has adopted two recommendations significant for the effective administration of cities (Dimitrijevic \& Vucetic, 2011: 143). Bearing in mind that the subject of this paper is primarily the internal decentralisation of larger cities, especially their administrative structure and competences, this article does not address many questions which have been discussed by other authors (Ilić, 2001; Pavić, 2001; Koprić, 2009; Jacobs, 2010), such as the criteria for obtaining the legal status of a city.

The subject of analysis is the decentralisation of city governance in Europe and the competences of decentralised city units in European cities. In the second part of the paper the research focuses on the statutes of Serbian cities, as primary legal sources, for the purpose of examining the internal decentralisation of Serbian cities, the conceptual framework and legal nature of these city units, the competences of city municipalities, and their organisational structure. The author has applied the standard methods of legal jurisprudence (comparative, historical, dogmatic, normative, and axiological methods) in order to provide a comprehensive systematisation of the analysed norms and draw conclusions on the legal nature of city municipalities in the Republic of Serbia.

\section{Decentralised City Units in European Countries}

Different countries regulate the organisation of the internal decentralisation of their major cities in different ways; however, all models can be divided into two large groups. According to the first model, a large city is joined together with its suburban areas into a single decentralisation unit - a metropolis - i.e. a self-governed decentralisation unit whose 
jurisdiction entails a set of original affairs. The second approach involves creating one or more single-purpose or multi-purpose authorities which perform their activities within the framework of city competences (Jovičić, 1974: 70; Dimitrijević \& Vučetić, 2012: 139). In most cases, especially in capital cities, the city government is organised in two layers, making provisions for a clear differentiation between the genuine self-governing units and the administrative branches of major city authorities within the scope of decentralised city units. We shall exempt from our research a large group of cities whose constituent units have an administrative character (Jovičić, 1974: 71).

The process of modern internal decentralisation of cities became prominent in the second half of the 20th century, with its first offshoot in Italy (in Bologna in the 1960s). Bologna's inner city decentralisation units were at first established as deconcentration units because they used to be appointed by the city government; they were directly elected from 1974, which resulted in the expansion of their competences. At the beginning of the 1970s, over 100 Italian cities followed the examples of Bologna, Venice, Rome, Milan, and many other large cities, thus inciting the legislator to react to the new circumstances by amending the systemic legislative act on local self-governance and allowing cities with more than 40,000 inhabitants to form inner city decentralisation units (Ivanišević, 2008: 411). However, regardless of the citizens' right to directly elect the members of representative bodies, chairpersons of executive authorities in decentralised units were initially elected by city representatives (CoE, 1996: 30). The Italian model was adopted by a number of Spanish cities.

In German cities, the first units of internal decentralisation (with directly elected authorities and original competences) were created in the mid1970 s; consequently, by the early 1980s, approximately $85 \%$ of cities with over 95,000 inhabitants had instituted genuine internal decentralisation (Ivanišević, 2008: 409). According to the type of decentralisation and their competences, decentralised city units in Germany are classified into four large groups (Ivanišević, 2008: 410). The first group comprises the districts of large cities with the largest population, which are concurrently federal units (e.g. Berlin and Hamburg); the second group includes the districts of cities in Northern Germany (e.g. Cologne is divided into 9 city districts with an average population of 110,000 inhabitants) $;{ }^{1}$ the third

${ }^{1}$ However, is it disputable whether they are self-governing inner city decentralisation units or deconcentration units. 
group covers the districts of cities in Southern Germany (e.g. Munich is divided into 41 inner city units with an average population of 30,000 inhabitants) with relatively smaller population numbers; and the fourth group comprises the districts within those cities whose territory is not entirely divided into city districts. With certain modifications, the German model has been applied in Austria, Switzerland, and Holland.

In France, the process of internal decentralisation began almost a decade later (in 1982), but only in three large cities: Paris, Marseilles, and Lyon. Two thirds of the city unit representatives were elected directly, and one third was composed of city representatives elected on the territory of the internal decentralisation unit, which eventually served as the basis for electing the head of the city unit and his/her deputies (Ivanišević, 2008: 412; CoE, 1996: 16). Initiative, consultative, and diverse committees were constituted as special bodies of internal decentralisation which included representatives of associations holding public services on their territory. Obviously, this model did not represent full decentralisation, as a result of which these units were vested with a small number of original competences. Later on, the application of this model was optionally expanded onto cities and city units with more than 100,000 inhabitants.

In Nordic cities (in Sweden, Norway, and Denmark), members of committees as principal authorities of city units are appointed by the city council; hence, they cannot be regarded as internal decentralised units despite the fact that some authors refer to them as such (Ivanišević, 2008: 415).

As for Central European countries, we can point out that inner city decentralisation units are not generally accepted as a solution to problems that large cities are facing, and that this model is largely used in the capitals.

In 1990 Poland introduced a special form of urban self-governance units, the so-called "subsidiary units" (a model implemented in only a few major cities); thus, the three-tier organisation of Warsaw was regulated by a special law (lex specialis) in 1994, which caused serious problems in city administration due to the unclear distribution of competences (Ivanišević, 2008: 417).

As opposed to Czech cities, which are organised as single units and not internally decentralised, Bratislava and Košice in Slovakia are divided into city districts as self-governing units of internal decentralisation with their own executive powers. The same model has been introduced in Budapest, which is the only city in Hungary divided into internal decentralisation units.

A very interesting solution has been applied in Bulgaria. In this country large cities do not have decentralised city units; however, within the basic 
decentralisation units of the rural type, it is possible to establish special local community offices which include settlements with over 5,000 inhabitants, whose heads are elected directly by citizens.

\subsection{Distribution of Competences}

The criteria for specifying the competences of the city and its parts, especially when referring to the so-called classical public offices and services, should be established in accordance with the principle of subsidiarity. Therefore, major city authorities should only be vested with those functions which would be more efficient if performed in a wider area (in case a city has been internally decentralised). Given the above, it is essential that there is a particular group of administrative affairs that constitute the core competences that should be granted to major city governments, ${ }^{2}$ such as: economic development, urban and land planning, public transport, establishment and development of industrial zones, typical utility services (energy and water supply, collection and disposal of waste and wastewater, transportation, health care services, and rescue and firefighting services), environmental protection, and city infrastructure. The situation is similar in capital cities. If city districts are internal self-governing units, the distribution of competences is regulated by law. In cases where the constituent units are established by capital cities, and when there is hierarchy among the constituent units, the "central" city government has much broader competences. Typical competences of central city governments are: creating a development plan for the entire city, public transportation, hospitals and special health services, public law and order, the police, public utility services, and road maintenance; on the other hand, typical competences of local decentralised units are: social security, primary health care, elementary education, environment protection, culture, and sports and recreation (Dimitrijević \& Vučetić, 2011: 147).

As far as European cities are concerned, we can conclude that there is no unique model of internal organisation. Moreover, the position of major cities in the administrative systems of European states is most frequently regulated within the framework of systemic legislation on local self-government; hence, major cities are granted the status of self-governing units whose position is equal to the position of districts (upper-tier units). Spe-

2 The term major city does not imply a hierarchical relationship between the city as a whole and its constituent decentralised units. 
cial legal status is usually given to the internal units of capital cities, while other large cities seldom pursue such a status unless such an option is explicitly envisaged in the applicable law. In any case, internal self-governing units are a second tier of governance within the city; in fact, no European city has built its internal local self-government on more than two tiers of self-government (e.g. city municipalities and local communities).

\section{Internal Decentralisation of Serbian Cities}

According to Article 12 of the Constitution of the Republic of Serbia of 2006, the right to local self-governance is defined as a basic citizens' right, which imposes some limitations on the powers of state authorities (Pajvančić, 2009: 242). By adopting systemic legislation in this field (the Local Self-Government Act, the Territorial Organisation Act, etc.), the territory of Serbia has been decentralised into provinces, the City of Belgrade, cities, and municipalities. The monotypic nature and one-tier organisational structure of the existing system is partially moderated by vesting special competences in the cities and the City of Belgrade, whose municipalities have the status of legal entities (with some elements of self-governance) even though they do not hold the status of decentralised units de iure. ${ }^{3}$ The 2007 Local Self-Government Act explicitly defines the city (as well as the municipality) as a form of local self-government unit. Under the provisions of this act, the municipality is "a basic territorial unit where local self-government is exercised through relevant authorities; it shall exercise all the rights and duties within its jurisdiction through relevant local bodies, and it shall include at least 10,000 inhabitants". The city is a unit of local self-government regulated by law, which represents an economic, administrative, and cultural centre for a wider area, and has more than 100,000 inhabitants - in exceptional cases involving specific economic, geographic, or historical reasons city status may be granted to a decentralised unit which does not meet the requirement on the specified

3 This was also confirmed by the Serbian Constitutional Court decision UI-199/2004, which stated that the status of local self-government unit is acquired in accordance with the constitution and legislation regulating the system of local self-government; thus, it is the city that has the status of a local self-government unit, not the city municipalities as its constituent parts. 
number of inhabitants. ${ }^{4}$ The city territory must be a natural, geographically and economically connected, area with a well-developed infrastructure and communication system between its constituent settlements, and the city centre as a gravitational hub. Under the Local Self-Government Act, all legal provisions regulating the operation of municipalities shall also apply in regulating the activities of the city.

\subsection{The Concept of the City Municipality as a Form of Internal Decentralisation in Serbia}

According to the provision contained in Article 189/4 of the Constitution of Serbia, city authorities are given discretionary power to establish city municipalities by enacting legislative acts called statutes. This provision necessarily involved a change to the former legal solution, which was in force until 2006 and which implied that the necessary prerequisite for obtaining city status was the establishment of at least two city municipalities. The city statute has become the fundamental constitutive legal act by means of which city municipalities are established, organised, and abolished, given the fact that it regulates the activities, competences, and organisational structure of city municipalities. The exception to the rule is the capital of the Republic of Serbia, the City of Belgrade (inhabited by 2 million people); according to Article 6 of the Capital City Act, the establishment of city municipalities is mandatory in the City of Belgrade. A city municipality in the Republic of Serbia may be defined as a special form of internal decentralisation unit with the status of a legal entity of public law. Under the city statute, its bodies are directly elected by citizens by popular vote, and it is entrusted to perform specific delegated activities from the scope of city competences. Notwithstanding the ambiguous and declarative standpoint of the legislature that city municipalities are not local self-government units, due to the fact that they have their own self-government (including their municipal assembly comprised of members directly elected by citizens, and their administrative and executive bodies) and that they have the capacity of a legal entity, it is irrefutable that they are a special, partly optional, type of internal decentralisation

4 Thus, under the 2007 Local Self-Government Act, there are 23 cities on the territory of Serbia, excluding Kosovo. In addition to the 5 existing cities, 19 municipalities were granted city status. A total of 9 cities were established by applying both conditions, while the remaining 10 cities were established by virtue of exception (Vučetić, 2007: 42). 
unit, deprived of full legal status. In any case, the legal position of city municipalities is weaker than the position of municipalities envisaged as basic local self-government units, whose organisation and functions are guaranteed by the Constitution, the Local Self-Government Act, and the Territorial Organisation Act.

Considering that the legal provisions in this field regulate neither the criteria for establishing city municipalities nor their organisational and operative structure, further on in this paper we shall present a synthesis of normative solutions from the statutes of those Serbian cities which have established city municipalities (Belgrade, Niš, Novi Sad, Požarevac, Užice, and Vranje), the aim of which is to clarify the characteristics and organisational structure of the existing Serbian city municipalities.

City municipalities have been established in six out of a total of 24 Serbian cities. On the territory of the capital city of Belgrade, there are 17 city municipalities (Barajevo, Voždovac, Vračar, Grocka, Zvezdara, Zemun, Lazarevac, Mladenovac, Novi Beograd, Obrenovac, Palilula, Rakovica, Savski venac, Sopot, Stari grad, Surčin, and Ćukarica); the city of Niš comprises 5 city municipalities (Medijana, Niška banja, Palilula, Pantelej, and Crveni Krst); the city of Novi Sad includes two city municipalities (Novi Sad and Petrovaradin); Požarevac has two city municipalities (Požarevac and Kostolac); Vranje has two city municipalities (Vranje and Vranjska Banja); and Užice has two city municipalities (Užice and Sevojno) (Statistical Office of the Republic of Serbia, 2012: 15).

In Belgrade, there are three types of city municipalities: urban (Stari grad, Vračar, Savski venac, and Novi Beograd); mixed (Zemun, Ćukarica, Voždovac, Zvezdara, Palilula, and Rakovica); and suburban (Barajevo, Grocka, Lazarevac, Mladenovac, Obrenovac, Sopot, and Surčin)..$^{5}$ In terms of the number of inhabitants, six of these city municipalities (Novi Beograd, Ćukarica, Voždovac, Zvezdara, Palilula, and Zemun) are equal in size to the largest Serbian cities, which is why there are initiatives to establish new city municipalities on the territory of the capital city of Belgrade (Orlović, 2009: 71).

Article 6/2 of the Capital City Act contains a provision on the most appropriate circumstances in which to establish city municipalities; i.e. when it is required for a more economic and efficient performance of certain duties and activities of the city. It is interesting that the legislator places greater emphasis on the principle of efficiency than on the principle of

5 A similar classification of city municipalities can be made in other cities. For example, in Niš only one city municipality (Medijana) is entirely urban. 
subsidiarity and greater democracy in the city system. In addition, the provisions contained in Articles 20-24 of the Statute of the City of Belgrade precisely regulate the procedure for changing its territorial organisation, which may serve as a guideline for other cities whose statutes still do not regulate this subject matter. Historical records prove that the City of Belgrade has always been subject to frequent administrative changes and adjustments in response to the constant growth of its population.

\subsection{Historical Development of City Municipalities in the Republic of Serbia}

A city municipality, as a unit of local self-government and a legal category, is not a new phenomenon in Serbia. In the multi-type system of local self-government, established by the Law on the Organisation of Municipalities of 1839, city municipalities were the basic form of local self-government units, alongside rural municipalities. In 1934, the Law on City Municipalities was passed (together with the Law on Municipalities); therein, the legal status of city municipalities was made equal to that of ordinary municipalities and they were given broader powers, such as the right to give their opinions on legislative acts and other matters, as well as the authorisation to perform certain deconcentrated duties of state administration (Dimitrijević \& Vučetić, 2011: 189).

City municipalities became part of the legal system after World War II, as a response to the issues concerning the organisation of large cities. In that period, the City of Belgrade was divided into two districts which included the suburban areas and so-called zones, providing space to include parts of Zemun, Vračar, and Podunavlje into the so-called District of Belgrade in 1955. The Constitution of 1963 envisaged the possibility of dividing a city into city municipalities, which was initially done by six cities: Belgrade, Zagreb, Sarajevo, Skopje, Ljubljana, and Maribor (Jovičić, 2006: 79). The number of municipalities in Belgrade kept growing over time, thus fully confirming the tendency towards differentiating administrative institutions and organisations. In 1965 there were thirteen city municipalities; in 1971 Belgrade comprised fifteen city municipalities. In 1974, having separated from Ćukarica, Rakovica became the sixteenth municipality of Belgrade. In 2003, the Surčin municipality became independent from Zemun (Vukotić-Lazar, 2008: 7).

On the other hand, the city of Novi Sad featured a more firm, hierarchical organisation, given the fact that in the period between 1980 and 
1989 it was made up of seven city municipalities: Stari Grad, Podunavlje, Liman, Slavija, Petrovaradin, Detelinara, and Sremski Karlovci. In 1989, a single city municipality of Novi Sad was established by joining together the six municipalities, while the municipality of Sremski Karlovci was excluded from the internal city structure and became an independent local self-government unit.

After 1990, and after passing the Territorial Organisation Act of the Republic of Serbia and the Local Self-Government Act, there was a tendency of forced establishment of city municipalities, which was a prerequisite for gaining city status. In the period from 2002 to 2008, Kragujevac was divided into five city municipalities, which were later abolished by amendments to the city statute. Novi Sad was divided into two municipalities. Niš was initially divided into two city municipalities and later into five municipalities. In the internal structure of the city of Požarevac city municipalities were established in 2009; in the city of Vranje, they were established in 2010.

\subsection{Competences of City Municipalities in the Republic of Serbia}

Considering the question of competences of Serbian decentralisation units, a double-track system has been implemented, according to which the competence of decentralised units falls within the scope of compulsory competences, which departs from the classical Central European model where genuine self-governing competences are divided into compulsory and optional.

The consequence of the constitutional solution according to which city municipalities do not have the status of local self-government units lies in the fact that they do not have their self-governing competences, but that they conduct some competences they have been delegated under the statute. In addition to self-governing competences delegated by the central city government, certain city municipalities in Serbia perform sub-delegated competences of the state administration (e.g. Novi Beograd). Taking into account the nature of these competences, city municipalities cannot perform further sub-delegation of these competences, as confirmed by the Constitutional Court in 2009 (decision UI no. 45/2009), which declared unconstitutional the decision of the Palilula city municipality in Belgrade to provide legal assistance to citizens by engaging members of Belgrade Bar Association. 
The second consequence of the deprived legal status of city municipalities in Serbia lies in the fact that the nomotechnical principle which was applied in determining their competences - the enumeration principle - departs from the principle of subsidiarity. In their statutes, cities specifically enumerate the activities of their city municipalities in order to prevent a conflict of competences. Apart from the statute of the city of Novi Sad, all other city statutes leave room for municipalities to: "perform other activities of direct interest to citizens, in accordance with the law, the statute and other provisions of the city."

Furthermore, given the fact that this matter is regulated by city statutes, activities of city municipalities vary in different cities. It is therefore necessary to compare them.

All city municipalities in Serbia enact the statute ${ }^{6}$ the budget, and the annual financial statement (balance sheet); give their opinion about the urban development programme, and spatial and urban planning that refer to the territory of the city municipality; regulate and ensure the performance of activities related to construction, maintenance, protection, use, and management of local and uncategorised roads; monitor the situation and take measures for the protection and management of the environment on their territory; and make decisions on establishing, abolishing, and organising the territory of local communities and other forms of local self-government. ${ }^{7}$

Except for the city municipalities of Novi Sad, Belgrade, Niš, Požarevac, Užice, and Vranje, city municipalities adopt programmes and manage urban development projects, make provisions for the improvement of the general framework of economic activity, ensure the observance of communal public order on their territories, promote the development of culture and creative arts, provide conditions for organising cultural events of significance for the population, monitor and provide for specific needs in the field of sport, and provide conditions for organising sports competitions. Moreover, the city municipalities of the aforementioned cities make provisions for the development of the catering industry, crafts, and tourism on their territories; regulate the organisation and work of mu-

6 The only exception is the city of Novi Sad, according to whose statute city municipalities decide on their own organisation and scope of work.

${ }^{7}$ In comparing the normative solutions contained within the statutes of city municipalities in Serbia, the author has largely relied on the research conducted by Saška Milošević in 2012 for the purpose of writing her master's thesis entitled "City Municipalities" at the Faculty of Law in Niš. 
nicipal conciliation panels (for peaceful dispute resolution); ensure legal assistance to citizens and encourage the development of different forms of self-help, solidarity with persons with special needs; and regulate and ensure the use of the name, emblem and other symbols.

The city municipalities of Belgrade, Požarevac, Užice, and Vranje have certain competences in the field of agriculture (e.g. to ensure its development and improvement, to implement protection measures, and to decide on the application and improvement of agricultural land on their territory), the management of their own assets and the usage of state assets, exercising youth rights (e.g. the adoption and implementation of a youth action plan), establishing communal utilities companies, and public dissemination of information (on issues important for the life and work of citizens on the territory of the city municipality).

Taking into account the urban character of some of its municipalities, Belgrade and Novi Sad have not transferred the authority to promote and develop co-operatives to their constituent municipalities, which is a highly disputable solution considering the fact that not all municipalities in Belgrade are urban ones, and that some of them are suburban.

The only activities that the city municipalities of Belgrade cannot conduct are those concerning protection against natural and other major disasters, protection against fire, and elimination and mitigation of fire effects. Moreover, the municipalities of Belgrade and Požarevac have no competences in the area of keeping and protecting domestic and exotic animals. The city municipalities of Belgrade, Niš, Užice, and Požarevac propose measures to the city for the organisation and maintenance of the external appearance of commercial and residential buildings; they also keep a record of the maintenance of residential buildings, and prescribe misdemeanour penalties for the violation of these regulations.

The city municipalities of Belgrade, Užice, and Požarevac are obliged to ensure the exercise, protection and promotion of human rights, which is apparently a competence of a declarative nature, as the city municipalities of Požarevac are the only ones which are explicitly given the authority to cooperate with humanitarian organisations in performing their activities.

The city municipalities of Požarevac and Vranje have no competence in the domain of evicting illegal tenants from apartments and common storage/utility areas in residential buildings, nor do they have the competence to decide on setting up prefabricated buildings on public land. In addition to these two cities, the city municipalities of Belgrade are not authorised to regulate and determine the manner of using and managing rural water 
supply systems, water springs, public wells, and fountains. They are also not authorised to make decisions on the use of pastures and their conversion into arable land, ${ }^{8}$ nor are they authorised to decide on the maintenance or management of cemeteries on their territories.

The cities of Belgrade, Niš, and Užice have vested their municipalities with some competences that other urban municipalities do not have; thus, they can regulate and provide for the use of business office premises under their management, determine the fees to be charged for the use of these premises, and supervise their use.

The Niš city municipalities are the only ones in Serbia which have been vested with the authority to draft civil defence plans for their municipal territory, in compliance with the applicable city plan.

Pursuant to Article 77 of the Statute of Belgrade, the Belgrade city municipalities are the only ones in Serbia which have been entrusted with the following competences: to make strategies of local importance; to alienate and lease construction land in public ownership, in accordance with the applicable law and a decision of the city, for the construction of objects up to $800 \mathrm{~m}^{2}$ of the total building area (except in cases involving direct settlement in legalisation proceedings); to decide on requests for the annulment of legally enforceable decisions on the exemption (of one's estate) from the construction land owned by the city; to decide on requests to terminate the right to use the construction land (in case the decision on the right to use the land for construction purposes was issued by the competent authority of the city municipality); to make first instance decisions on the construction permit for building or reconstructing objects up to $800 \mathrm{~m}^{2}$ of the total area, and decisions on converting common storage and utility areas in residential buildings into residential space or business premises; to perform supervision and inspection activities over construction projects whose construction permits have been issued by the city municipality; to monitor and provide for the maintenance of kindergartens and elementary schools; to monitor the process of enrolment in primary schools and schools for children with special needs; and to supervise regular attendance in primary schools and initiate misdemeanour proceedings against parents or guardians. This group of competences also includes the organisation of activities pertaining to: the transportation of preschool

${ }^{8}$ Due to its completely urban character, the Medijana city municipality in Niš does not have this competence, nor the competence to participate in preparing development programmes for the construction, service, management, and use of country roads, field roads, and other uncategorised roads. 
children and their caretakers at distances greater than 2 kilometres for the purpose of attending a preparatory preschool programme, as well as transportation of elementary school children at distances greater than 4 kilometres from the school; transportation, accommodation and nutrition for children and pupils with disabilities, irrespective of the distance between their place of residence and the school; transportation of children to national and international contests; adoption of measures and activities for the protection and safety of children and pupils during the educational process and other activities organised by the educational institution; legal protection of the rights and interests of the municipality; and, optionally, the establishment of a municipal ombudsman with relevant authorities within the territory of the city municipality. In addition to all these competences which have been granted to all city municipalities of Belgrade, the city municipalities of Barajevo, Grocka, Lazarevac, Mladenovac, Obrenovac, Sopot, and Surčin are authorised to provide conditions for the efficient operation and development of communal utility services. In that context, they may establish public offices; issue construction permits for the building and reconstruction of roads and facilities of linear and/ or communal utility infrastructure on their territory; give information on building locations and location permits for facilities for which they issue a building permit; decide on the names of streets, squares, villages, and other parts of an inhabited settlement on their territories; and raise monuments, put up memorial plaques, or sculptures.

Under the Statute of Novi Sad, competences vested only in the city municipalities of Novi Sad are as follows: giving opinions on planning documents and reports on the performance of public utility companies and offices; issuing urban planning permits for individual residential buildings (family houses, outbuildings, and garages) as well as allotment permits; making decisions on the temporary use of public traffic surfaces in the streets and on local roads ${ }^{9}$; maintaining, proposing measures, and providing conditions for the development and maintenance of urban open spaces, public green areas, playgrounds, public lighting facilities, and traffic signs (these competences are also granted to the city municipality of Sevojno in the city of Užice); undertaking activities aimed at promoting farming; keeping records on good-quality and select male breeding animals, and deciding on the conditions for performing certain activities to ensure the quality of livestock; regulating the terms and conditions for

9 Except for the area which was covered by the General Plan of the City of Novi Sad until 2001. 
keeping bees, setting up apiaries and determining the area for the selection of bees; providing conditions for chimney sweeping services; and providing conditions for the improvement and maintenance of open markets that do not fall under the competence of the city.

Unlike some other municipalities, the city municipality of Sevojno in Užice has certain competences within the field of environment protection, such as: deciding on environmental issues and environment taxes and fees; adopting plans for the conservation and protection of the environment; providing conditions for the preservation, use, and development of natural parks and areas known for their medicinal properties; and promoting the activity of (and providing assistance to) organisations dealing with persons with disabilities and other humanitarian organisations operating within its territory.

\subsection{Organisational Structure of City Municipalities}

The city municipality assembly. As confirmed by the Serbian Constitutional Court (Decision UI-199/2004), the provisions of the Local Self-Government Act regulating the bodies of local self-government units do not refer to the bodies of city municipalities, whose structure and organisation are autonomously defined in the statute of each individual city. In spite of this fact, the vast majority of city municipalities have copied the organisational structure of municipalities operating as full-fledged local self-government units. This solution is inefficient and represents a financial burden for the functioning of the cities.

With the exception of those of Novi Sad, all city municipalities have the following bodies: the city municipality assembly, the municipality chairperson, the city municipality council, and the city municipality administration. In the city of Vranje, city authorities are concurrently the bodies of the city municipality of Vranje, whereas the city municipality of Vranjska Banja has bodies similar to those mentioned above, given the fact that activities of city administration are conducted by the municipal administrative unit. The city of Novi Sad has taken a significant step forward in terms of its statute, but, unfortunately, not in practice. Thus the two municipalities in Novi Sad have two bodies: the city municipality council and the municipal administration, whereby the legislative and the executive branch of the local government operate as a whole in the city municipality council. Unfortunately, there is no opportunity to see how such an organisational framework would work in practice. 
According to the provisions of their respective statute, city municipality assemblies formally have the highest position in the organisational structure of municipal authorities; municipal assemblies are composed of members elected by citizens in direct elections by secret ballot, and whose number varies from 15 to 75 in different city municipalities. ${ }^{10}$ Members are elected every four years; they cannot be employed in the municipal administration and they cannot be persons appointed by the assembly. As there are no original competences whose exercise should be regulated by general acts and decisions of municipal assemblies, a question may be raised regarding the purpose of such a classic representative body, whose operation is necessarily accompanied by numerous committees and expenses. In the city of Niš, in 2004, both municipal assembly and municipal council chairpersons were elected, while the assemblies themselves did not exist.

Competences of city municipalities can be roughly divided into three main groups: the quasi-normative, organisational, and initiative-proposing competences. The first group of competences includes the adoption of the city municipality statute and rules of procedure, the budget and the annual financial statement on the city municipality budget, as well as the city municipality development programme. The second group of competences includes: establishing local communities and other forms of local self-government; establishing bodies, organisations, and services to meet the needs of city municipalities and regulating their operation and coordination; establishing public companies (apart from Belgrade city municipalities, this competence is also given to Vranje city municipalities), institutions and other organisations envisaged in the city statute; and appointing and discharging members of administrative and supervisory boards in public companies. Yet the most significant among these competences are certainly the election and revocation of the city municipality chairperson and his/her deputy, as well as members of relevant working bodies. In addition, the city municipality assembly makes decisions on cooperation and association with local self-government units in the country and abroad, which is another indicator of the genuine self-governing character of city municipalities. The third group of competences includes: giving opinions on city spatial planning, calling a referendum, and providing consent to the use of the city municipality coat of arms.

10 Belgrade city municipality assemblies have between 19 and 75 members, Niš has between 19 and 27 members, in Požarevac there are 21 members, and in Vranje there are 15 members. 
Adoption of ethical codes of conduct for city officials and employees is still not an obligatory responsibility of all city municipalities, although it should be; for example, the statutes of Niš and Novi Sad do not envisage such an obligation.

The city municipalities of Požarevac can establish public institutions (such as a cultural centre which manages all museum, tourist, and sporting activities) but it cannot establish public companies.

Belgrade city municipality assemblies have greater powers that any other city municipalities in Serbia, which is to a certain extent natural, given their position and the size of the capital. ${ }^{11}$

A very rare principle of co-optation has been applied in the work of permanent working bodies (various committees, councils, and commissions) of city municipality assemblies. Their members are appointed and dismissed by the assembly, but more than half of the members must be ordinary citizens. ${ }^{12}$ The number of these working bodies is high and their actual influence is minor; therefore it can be concluded that they are an unnecessary burden for the operation of city municipalities, which certainly increases overall costs.

11 These powers include: adopting strategies of local importance in accordance with city acts; establishing public prosecution offices, appointing, and dismissing the municipality public prosecutor and his/her deputy; the possibility of establishing the municipal ombudsman and his/her appointment and dismissal; deciding on remunerations for council members and members of working bodies; deciding on the management of municipality assets and the use of state assets; deciding on municipal borrowing; deciding on the names of streets, squares, villages, and other inhabited areas; deciding on raising monuments, setting up memorial plaques, or sculptures (this competence is held by those city municipalities which have additional competences in comparison with the rest of Belgrade municipalities); adopting a youth action plan; adopting acts which determine measures and activities for protecting and securing children/pupils during the educational process; deciding on cultural and sports events important for municipalities; reviewing operative reports, financial reports, and giving consent to the work programmes of public communities, including the financial programme of public offices (the Council of Novi Sad City Municipalities provides an opinion on planning documents and reports on the work of communal utilities services and other public offices, discussed by the assembly); and prescribing penalities for violating municipal regulations.

12 For example, the permanent working bodies of the Niš city municipality of Crveni Krst are: the Commission for Administrative, Mandate and Immunity Issues; the Commission for the Work of Local Self-Government; the Commission for Education, Sports and Youth; the Commission for Agriculture; the Commission for Social and Health Issues; the Commission for Utility Services; the Commission for Economy and Development; the Commission for Gender Equality and Equal Opportunities; and the Commission for Cooperation with other city municipalities in the country and abroad. 
Executive bodies. Executive bodies of city municipalities are the chairperson of the city municipality and the municipal council (except for Novi Sad as before).

All chairpersons represent their city municipalities, propose ways of solving certain issues within the competence of the city municipality assembly, order the city municipalities' budget payments, direct and coordinate the work of the city administration, and adopt individual and other acts.

Some chairpersons may establish advisory bodies (in Belgrade, Vranje, and Požarevac), some are obliged to submit reports on their work to the assembly of the city municipalities (in Niš and Požarevac), and some are allowed to conclude contracts on donations with natural and legal persons (in Belgrade and Požarevac), etc. The Belgrade city municipality chairpersons have the largest number of competences. ${ }^{13}$

The second body of executive power is the council of city municipalities, which, as a rule, consists of five members, except for Belgrade city municipalities, which have eleven members. Their main responsibilities are: to propose the statute, budget, and other acts within the competence of the city municipality assembly; to supervise the work of the city administration and annul improper acts; and to act as a second-instance authority for decisions on the rights, duties, and obligations of citizens, companies, and institutions in matters within their jurisdiction.

Additionally, the council can establish professional working bodies (in Belgrade and Vranje), co-opt citizens as their members, appoint and dismiss the head of the city municipal administration (in Belgrade and Požarevac), adopt a temporary budget (in Belgrade and Požarevac), etc. The councils of city municipalities in Niš are obliged to submit regular reports on their work to the city municipality assembly. As with other city municipality bod-

13 Acting on behalf of the municipality, they conclude collective agreements for institutions, companies, and other public offices founded by the assembly; they adopt the book of rules on salaries and other reimbursements for the persons elected and appointed by the assembly and the municipal council, as well as the salaries of employees and appointed officials in the city administration; they appoint and dismiss deputy chairmen of the city municipality; they give consent on general acts concerning budget users, institutions, and offices established by the assembly and regulating the structure and number of employees; they organise municipal council activities, assign direct tasks to members of the council, and determine who shall be permanently appointed members of the council in the city municipality; they decide on state-owned financial assets in accordance with the law; they decide on the acquisition and disposal of the equipment of greater value for purposes of municipal bodies; and they propose acts before the assembly on public debt and perform other activities stipulated in the statute. 
ies, the councils of Belgrade municipalities have a large number of competences which the councils in other city municipalities do not have. ${ }^{14}$

The city municipality administration is established as a single body which is in charge of performing administrative activities in city municipalities, while the head of the city municipality administration is the chief administrative officer. Other units of internal organisation may be formed within the city administration,,$^{15}$ and these are headed by administrative officers. The city municipality administration deals with administrative and specific professional activities pertaining to the exercise of rights and interests of natural and legal persons; therefore these activities must be performed by persons of an appropriate educational background, who have passed professional examinations for working in state bodies, and who have relevant work experience. The second main group of activities of the city municipality administration includes administrative supervision over the execution of general acts of the municipal assembly. Following a public call for the position, the chief administrative officer is appointed by the city municipality council and serves a five-year term of office. ${ }^{16}$ However, even though he/she is appointed by the council, the chief administrative officer submits reports on his/her work both to the council and to the city municipality assembly. The council will hold the chief administrative officer accountable if the assembly does not accept the report on the work of the city administration or if the chief administrative officer fails to submit the report.

Internal relationship between city authorities and the city municipality. The relationship between city authorities and city municipalities is based on

14 They give consent to the financial plan, budget users' plan, and local community plan; they take into consideration their reports and work programmes, except for public companies; they direct the competent city administration authority to take part in the preparation of city regulations whose content is of high importance for exercising the rights and duties of municipalities; they ask competent city authorities for an opinion on the amendment of regulations and other general acts of the city; they give initiatives to city authorities for the regulation, adoption, or amendment of regulations under city jurisdiction; they initiate actions significant for the regulation of the rights and obligations of the municipality; they initiate the procedure for the assessment of the constitutionality or legality of this act or other general acts of the Republic of Serbia or the city, which violate the right of the municipality; and, upon request, they provide information and response to the constitutional court.

15 Except for Novi Sad, where the establishment of internal units is not allowed.

16 The job requirements are: a diploma (LLB degree) from the Faculty of Law, a passed professional examination for working in state administration bodies, and at least five years of professional work experience. The chairperson can have one assistant but in Belgrade this number goes up to three for certain administrative areas. 
the principle of hierarchical supervision, whereas the mutual relations between city municipalities are based on principles of cooperation and agreement. In the course of performing their activities, city authorities inform city municipality bodies and services (either upon the request of the city municipality authorities or upon the initiative of city authorities) of issues of interest for the operation of city municipalities and local self-government; this duty is often neglected by city authorities. In that respect, city authorities are required to: ensure the participation of city municipality chairpersons in the drafting of city regulations significant for the city municipality; provide professional assistance to city municipality authorities and services; request reports, data, and information on city municipality performance; and give consent to some general legislative acts, such as the act regulating the number and structure of city municipality employees.

On the other hand, while performing the activities within their competence, city municipality authorities are entitled to initiate the adoption or modification of regulations in a specific area within the competence of the city; they may call for the introduction of appropriate measures important for the operation of city municipalities; and seek opinions on the application of city regulations and participate in their drafting (if their content is of particular importance). In case of envisaged supervision over statutory acts adopted by the city municipality assembly and its operation, the city municipality chairperson and the secretary of the city municipality assembly shall be accountable for the timely submission of data, files, and documents to that effect.

Should a city municipality body fail to perform their competences envisaged in the statute for over a month, it shall be issued a warning. Following the expiry of another month from the date the warning is issued, the city assembly (or the body authorised by the assembly) shall undertake the performance of those competences, suspending the transfer of financial assets, and taking appropriate measures to provide for the performance of specific activities in the city municipality.

In case of collision between the city municipality statute and the city statute, the city assembly shall refer to the city municipality assembly, identify the problem, and request from the municipal assembly to comply with the city statute by making relevant adjustments (to the municipality statute) within a reasonable, specified period of time. Further on, in case the municipal assembly has failed to comply with this request, the city assembly shall initiate a constitutional review proceeding for the assessment of constitutionality before the constitutional court, asking the court to suspend 
the execution of individual acts or activities which have been adopted or performed pursuant to that statute (in case the execution of these acts/ activities may give rise to irrevocable detrimental consequences).

In case of collision between a general legislative act adopted by the city municipality assembly, and the city statute or other regulations, the mayor (acting upon the proposal of the city administration, members of the city assembly, or members of the city municipality assembly) first issues a warning to the authority which has adopted the act and requires the municipality to make adjustments in compliance with the city statute or to repeal the act within (the envisaged) one-month period; thereupon, acting on the mayor's proposal, the city municipality assembly shall issue a decision on suspending the execution of this act, which shall subsequently be repealed or annulled. In such a case, the city assembly is obliged to initiate a constitutional review proceeding for the assessment of constitutionality before the constitutional court, asking the court to suspend the execution of any individual act or action/activity which has been adopted or performed pursuant to the general legislative act of the city municipality, in case the execution of this act/activity may give rise to irrevocable detrimental consequences. ${ }^{17}$

In specific circumstances envisaged in the statutes of the cities of Belgrade and Požarevac, when a city authority does not perform the activities within its scope of competences, the municipal assembly shall warn the city authority about the observed lapse and request from the city authority to perform the specific activity in accordance with the statute; thereupon, the assembly shall refer the disputed issue to the government of the Republic of Serbia, which is required to take measures in accordance with the applicable law.

The most radical measure which the city assembly has at its disposal is certainly the dissolution of a city municipality assembly, which is initiated upon the proposal of the city council and followed by the decision of the city assembly chairperson to call new elections for the members of a new city municipality assembly within a period of 60 days (i.e. 30 days in the city of Niš). Except for the statutes of Novi Sad and Niš, the statutes of all other cities in Serbia have thoroughly regulated the reasons for the dissolution of municipal assemblies, which may be dissolved in the following circumstances: in case the assembly has been inoperative for more than 3

17 Unfortunately, the statute of Niš, as opposed to other cities, does not specify the deadlines, nor does it envisage the obligation to initiate a constitutional review proceeding for the assessment of legality before the constitutional court. 
months, in case it fails to elect the chairman of the city municipality and the council within the prescribed period of one month from the constitution of the city municipality or from the date of the deputies' dismissal or resignation, or in case it does not adopt the statute or the budget within a prescribed time limit. Until the constitution of new representative and executive bodies of city municipalities, their current and urgent duties shall be performed by a temporary authority. ${ }^{18}$

In order to protect the rights of the city municipality and its citizens, the city municipality council may initiate a constitutional review proceeding for the assessment of constitutionality and legality of the acts which violate the rights of the city municipality; (this authority is given to the city municipality chairperson in Kostolac as well). A constitutional complaint may be filed with the constitutional court if an individual act or actions of a state authority, city authority, or municipal body interfere with the exercise of the competences of the city municipality.

In addition, city municipalities can protect their rights and interests by means of establishing a municipal public defender's office, whereas the city municipalities of Belgrade have their own public defenders. On the other hand, the statutes of the Kostolac and Niš city municipalities envisage that the city public defender's office shall perform these activities on their behalf.

\subsection{Local Community Units - The Third Tier of City Government}

The statutes of some city municipalities envisage the possibility of establishing local community units and other forms of local self-government aimed at satisfying the needs and interests of the local population in one or more villages, or an inhabited area with an approximately similar number of inhabitants (in Belgrade, Požarevac, and Niš). On obtaining the citizens' opinion, the city municipality assembly makes a decision to establish a local community unit by a majority vote of all assembly members; (the assembly is also authorised to decide on possible territorial changes

18 A temporary authority is formed even when elections for city municipality members are not held, or in the situation when (after regular elections) the assembly is not constituted within the period of two months from the announcement of the election results. The same radical measures are envisaged in Article 85 of the Local Government Act of 2007 in relation to the scrutiny of the state over local government units. 
to a local community unit and its abolition). The main authority and the representative body of a local community unit is the council. Local community units have been established within the Pantelej city municipality in the city of Niš. Members of the council of these local community units are delegated by the city municipality and their activities in this body are based on the principle of voluntarism. The composition of the council is proportionate to the number of representatives of particular political parties in the city assembly. Yet it is highly disputable whether it is justified to establish local community units in cities which have already established city municipalities, because organising the city administration in this manner will increase the number of vertical relations between different tiers of city authorities, thus exceeding the European standard.

\section{Conclusion}

All things considered, a number of conclusions can be drawn regarding the legal status of large cities. First of all, it should be noted that no provision of the European Charter on Local Self-Government requires the establishment of special internal units of decentralisation or any autonomous entities in cities. Yet Article 4/3 of the European Charter, which regulates the principle of subsidiarity, may be interpreted in this sense, given the fact that this principle supports the transfer of public activities and competences to local community units in the citizens' vicinity. Notwithstanding this fact and regardless of whether the internal decentralisation units include elected bodies or not, it is necessary to ensure the existence of a clear and open distribution of activities and competences between certain tiers of decentralised city units.

Considering the position of cities in the administrative and political system of a country, we can conclude that it is usually defined by the systemic legislation on local self-government. There are only a few countries which have enacted the Large Cities Act.

As for the model of organising city administration, one can observe that the organisation and constitution of city government bodies in certain countries differs from those in basic decentralisation units primarily because large cities are turning into potential decentralisation units. In this case, the structure of city administration is most frequently enhanced by the district model of organisation.

A special legal regime of internal decentralisation units (city municipalities or local community units) is most common in capital cities, while 
other large cities rarely opt for this even though it is envisaged in the law. Apparently, there is no general European model of internal decentralisation of large cities.

As far as the Republic of Serbia is concerned, the legal regime of local self-government does not recognise the concept of city municipalities as city decentralisation units; however, due to the direct election of their bodies by citizens, they may be designated as a type of decentralised self-governing unit deprived of full legal status given to ordinary municipalities.

Except for the City of Belgrade, the establishment of city municipalities and their organisational and operative structure remain largely in the discretion of city authorities, which regulate these issues in their statutes.

City municipalities do not have genuine self-governing competences but they are entrusted to perform all their duties in compliance with the city statute and the principle of enumeration, which is a direct consequence of their contradictory legal status. City municipalities cannot delegate the entrusted duties any further. The number and type of these responsibilities vary from city to city, and the only activities they all have in common are the activities in the field of urban planning, public roads, environment protection, and the establishment of local community units.

Considering the organisation of authorities in city municipalities, a vast majority of city municipalities have copied the organisational structure of ordinary municipalities which have the status of local self-governing units. Such a solution is inefficient and creates an unnecessary burden for the city and its operation. For this reason, it is worth considering some other models, or reinstituting those which formerly existed in the organisation of the city administration. For example, in the city of Niš in 2004, city municipality chairpersons and members of city municipality councils were elected, while city municipality assemblies did not exist at all. Today, a largely obsolete principle of co-optation has been used in the operation of permanent working bodies of city municipality assemblies and of their councils. Nonetheless, the number of these bodies (various committees, councils, and commissions) is rather high, and their actual influence is minor; therefore it may be concluded that they are an unnecessary burden for the operation of city municipalities, as they increase costs.

In the end, it is highly disputable whether it is justified to establish local communities in cities which have already established city municipalities, because organising city administration in this manner will increase the number of vertical relations between different tiers of city authorities, thus exceeding the European standard. 


\section{References}

Council of Europe, Steering Committee on Local and Regional Authorities. (1996). The status of major cities and their peripheries: Local and regional authorities in Europe (Report No. 59). Strasbourg, France: Council of Europe Publishing.

Dimitrijević, P., \& Vučetić D. (2011). Sistem lokalne samouprave [Local government system]. Belgrade, Serbia: Službeni glasnik.

Ilić M. (2001). Grad u lokalnoj samoupravi [City within local government]. Niš, Serbia: BCLS.

Ivanišević, S. (2008). Europska iskustva u decentralizaciji upravljanja velikim gradovima [European experiences in the decentralisation of big city governance]. Hrvatska javna uprava, 8(2), 407-420.

Jacobs, J. (2010). Gradovi i bogatstvo nacija: Principi ekonomskog života [Cities and the wealth of nations. Principles of economic life] (B. Aćamović Trans.). Novi Sad, Serbia: Mediteran Publishing.

Jovičić, M. (1974). Struktura i teritorijalna osnova lokalne samouprave u evropskim zemljama [Structure and territorial basis of local government in European countries]. Belgrade, Serbia: Savremena administracija.

Jovičić, M. (2006). Lokalna samouprava: Izabrani spisi Miodraga Jovičića, knj. 2 [Local self-government: Selected writings of Miodrag Jovičić, $2^{\text {nd }}$ book]. Belgrade, Serbia: Službeni glasnik.

Koprić, I. (2009). Decentralizacija i dobro upravljanje gradovima [Decentralisation and good governance of cities]. HJU, 9(1), 69-78.

Milošević, S. (2012). Gradske opštine [City municipalities] (Unpublished master's thesis). Niš, Serbia: Pravni fakultet.

Orlović, S. (2010). Podizanje kapaciteta političkih institucija grada Beograda. Belgrade, Serbia: Univerzitet u Beogradu, Fakultet političkih nauka.

Pajvančić, M. (2009). Ustavni okvir regionalne države: Primer Srbije. Novi Sad, Serbia: Centar za regionalizam.

Pavić, Ž. (2001). Od antičkog do globalnog grada [From antique to global city]. Zagreb, Croatia: Pravni fakultet.

Republički zavod za statistiku. (2012). Pregled promena administrativno teritorijalne podele kod opština u Republici Srbiji, 2002 - 2011 [Overview of changes in administrative territorial division of municipalities in Serbia, 2002 - 2011]. Belgrade, Serbia: Republički zavod za statistiku.

United Nations, Department of Economic and Social Affairs, Population Division. (2014). World urbanization prospects: The 2014 revision, Highlights. New York, NY: United Nations.

Vučetić, D. (2007). Most important changes in Serbian system of territorial decentralisation, FACTA UNIVERSITATIS - Law and Politics series, 5(1), 39-46.

Vujačić, M. (1981). Skupštinski sistem velikog grada: Sa posebnim osvrtom na Beograd [The parliamentary system of a big city: A special emphasis on Belgrade] (Unpublished doctoral dissertation). Belgrade, Serbia: Pravni fakultet 
Vukotić-Lazar, M. (Ed.) (2008). Organizacija i finansiranje grada Beograda, analiza $i$ uticaj na urbani razvoj [Organisation and financing of the City of Belgrade, analysis and impact on urban development]. Belgrade, Serbia: Urbanistički zavod Beograda.

\section{Legal Sources}

European Charter of Local Self-Government. (1985). Strasbourg: Council of Europe Constitution of Republic of Serbia. Official Gazette of the Republic of Serbia, No. 98/06

Capital City Act. Official Gazette of the Republic of Serbia, No. 129/07

Local Self-Government Act. Official Gazette of the Republic of Serbia, No. $129 / 07$

Local Self-Government Act. Official Gazette of the Republic of Serbia, No. 9/02, 33/04, 135/04, 62/06

Territorial Organisation of Republic of Serbia Act. Official Gazette of the Republic of Serbia, No. 129/07

Statute of the City of Belgrade. Local Government Act. Official Gazette of the City of Belgrade, No. 39/08

Statute of the City of Niš. Official Gazette of the City of Niš, No. 88/2008

Statute of the City of Novi Sad. Official Gazette of the City of Novi Sad, No. $11 / 2002$

Statute of the City of Požarevac. Official Gazette of the City of Požarevac, No. $4 / 2013$

Statute of the City of Vranje. Official Gazette of the City of Vranje, No. 23/11, $5 / 12,25 / 12$ and $32 / 12$

Statute of the City of Užice. Official Gazette of the City of Užice, No. 11/08

Statute of the City Municipality Barajevo. Official Gazette of the City of Belgrade, No. 30/2010

Statute of the City Municipality Voždovac. Official Gazette of the City of Belgrade, No. 36/10

Statute of the City Municipality Vračar. Official Gazette of the City of Belgrade, No. 45/08, 17/2010 and 44/2010

Statute of the City Municipality Grocka. Official Gazette of the City of Belgrade, No. 42/08, 17/10 and 59/11

Statute of the City Municipality Zvezdara. Official Gazette of the City of Belgrade, No. 43/08, 43/09 and 15/10

Statute of the City Municipality Zemun. Official Gazette of the City of Belgrade, No. $12 / 10$

Statute of the City Municipality Lazarevac. Official Gazette of the City of Belgrade, No. 43/2008 and 15/2010 
Statute of the City Municipality Mladenovac. Official Gazette of the City of Belgrade, No. 40/10

Statute of the City Municipality Novi Beograd. Official Gazette of the City of Belgrade, No. 3/2011

Statute of the City Municipality Obrenovac. Official Gazette of the City of Belgrade, No. 44/08, 4/10 and 15/10

Statute of the City Municipality Palilula. Official Gazette of the City of Belgrade, No. $43 / 08$ and $16 / 10$

Statute of the City Municipality Rakovica. Official Gazette of the City of Belgrade, No. 45/08, 10/10 and 7/12

Statute of the City Municipality Savski venac. Official Gazette of the City of Belgrade, No. 45/08, 18/10 and 35/10

Statute of the City Municipality Sopot. Official Gazette of the City of Belgrade, No. 45/08 and 12/10

Statute of the City Municipality Stari Grad. Official Gazette of the City of Belgrade, No. 3/11

Statute of the City Municipality Surčin. Official Gazette of the City of Belgrade, No. $44 / 08$ and $12 / 10$

Statute of the City Municipality Cukarica. Official Gazette of the City of Belgrade, No. 44/08 and 15/10

Statute of the City Municipality Medijana. Official Gazette of the City of Niš, No. $124 / 2008$

Statute of the City Municipality Niška Banja. Official Gazette of the City of Niš, No. $124 / 08$

Statute of the City Municipality Palilula. Official Gazette of the City of Niš, No. $123 / 2008$ and $109 / 12$

Statute of the City Municipality Pantelej. Official Gazette of the City of Niš, No. $123 / 2008$

Statute of the City Municipality Crveni Krst. Official Gazette of the City of Niš, No. $123 / 2008$

Statute of the City Municipality Kostolac. Official Gazette of the City of Požarevac, No. 2/2010

Statute of the City Municipality Sevojno. Official Gazette of the City of Užice, No. 20/2014

Constitutional Court Decision, IUI No. 45/2009. Official Gazette of the Republic of Serbia, No. 55/2010

Constitutional Court Decision IU No. 199/2004, Bulletin of the Constitutional Court of the Republic of Serbia. No. 1/05

Constitutional Court Decision, IUI No. 50/2009, Official Gazette of the City of Niš. No. 61/09 


\section{DECENTRALISATION OF CITY ADMINISTRATION AND COMPETENCES OF DECENTRALISED CITY UNITS}

\section{Summary}

A balanced city system, coordination, and cooperation between city units are necessary preconditions for effective city governance, as well as for avoiding internal imbalances and underdevelopment of city units. But the question is bow to achieve the required balance and equal development of all city areas. It is not always necessary to expand the autonomy of inner city units; sometimes it is enough to strengthen the mechanisms of cooperation, coordination, and information exchange in order to prevent the disintegration of the city systems. The first part of this paper focuses on the legal position of inner city units in European cities (primarily those in Central Europe, and to a lesser extent those in city conglomerates and metropolitan areas), with specific reference to their competences concerning the effectiveness of their administration and democratic processes. In the second part of the paper, the author provides a comprehensive analysis of the city administration and competences of city units in Serbian cities, which are internally divided into city units designated as city municipalities (gradske opštine). It can be concluded that neither Serbian local government regulations nor Serbian legal theory bave sufficiently defined the legal nature and position of city municipalities. It is easier to determine what a city municipality is not than what it is. In Serbia, only six out of twenty-four Serbian cities (including the capital of Belgrade) have established city municipalities. Due to the lack of normative provisions within the Local Government Act of 2007, this analysis focuses on the city statutes regulating the internal organisation of those six cities for the purpose of examining the administrative bodies and competences of Serbian city municipalities. These statutes do not regulate all the issues necessary for the successful operation of city municipalities; moreover, some city municipalities exist only in statutes rather than in reality.

Keywords: decentralisation, local government, cities, city municipalities, public administration 


\section{DECENTRALIZACIJA UPRAVLJANJA GRADOM I NADLEŽNOSTI DECENTRALIZIRANIH GRADSKIH JEDINICA}

\section{Sažetak}

Uravnotežen gradski sustav, koordinacija $i$ suradnja medu unutarnjim (decentraliziranim, submunicipalnim) gradskim jedinicama nužni su preduvjeti kako bi se učinkovito upravljalo gradom, te izbjegla neravnoteža i nedovoljan razvoj pojedinib dijelova grada. Postavlja se stoga pitanje kako postići traženi uravnoteženi gradski sustav. Odgovor ne leži uvijek u povećanju autonomije unutarnjih gradskih jedinica, već je ponekad dovoljno osnažiti mehanizme suradnje, koordinacije i razmjene podataka kako bi se spriječilo urušavanje gradskib sustava. U prvome dijelu rada razmatra se zakonski položaj unutarnjih gradskib jedinica europskih gradova - prvenstveno onih u središnjoj Europi, te nešto manje onih koji čine dio gradskih konglomerata $i$ metropolitanskih područja, s posebnim osvrtom na nadležnosti koje se odnose na učinkovito upravljanje i demokratske procese. U drugome dijelu rada detalino se analizira upravljanje gradom te nadležnosti gradskib općina - unutarnjï jedinica u koje su podijeljeni gradovi u Republici Srbiji. Zaključak je da pravna priroda i položaj gradskih općina nisu dovoljno dobro definirani ni teoretski ni pravnom regulacijom. Lakše je definirati što gradske općine nisu nego što jesu. Gradske općine oformilo je šest od ukupno 24 grada, uključujući Beograd. Kako Zakon o lokalnoj samoupravi iz 2007. ne sadrži normativne odredbe, u radu se analiziraju gradski statuti koji ureduju unutarnju organizaciju šest spomenutih gradova s ciljem razmatranja upravnib tijela i nadležnosti gradskib općina u Srbiji. No statutima nisu uredeni svi aspekti potrebni kako bi gradske općine uspješno funkcionirale. Štoviše, pojedine gradske općine i postoje samo na papiru, a ne i u stvarnosti.

Ključne riječi: decentralizacija, lokalna samouprava, gradovi, mjesna samouprava, javna uprava 